ISSN 0258-7122

Bangladesh J. Agril. Res. 36(2) : 285-290, June 2011

\title{
PERFORMANCE OF GLADIOLUS UNDER PROTECTED CULTIVATION IN THE RAINY SEASON
}

\author{
M. S. ISLAM ${ }^{1}$ AND A. F. M. E. HAQUE ${ }^{2}$
}

\begin{abstract}
An investigation was conducted with a view to observing the performance of two gladiolus genotypes during the rainy summer under poly tunnel production system. The genotype GL-027 produced taller plants $(73.8 \mathrm{~cm})$ with longer spike $(97.2 \mathrm{~cm})$ and longer rachis $(51.7 \mathrm{~cm})$ compared to the genotype GL-023. In respect of spike length $(97.0 \mathrm{~cm})$, rachis length $(54.4 \mathrm{~cm})$, weight of corm per plant (16.0g) and weight of cormel per plant (30.3 g), 1 July planting was better than in 1 May planting. Plants grown under poly tunnel produced flower earlier (82.5 days) compared to plants grown without poly tunnel (84.6 days). Although difference of only two days in flower initiation is of no significance, but plants grown under poly tunnel performed better in respect of number of florets per spike (12.8), number of cormels per plant (8.2), weight of corm per plant (16.0 g) and weight of cormels per plant (30.6 g) than the plants grown without poly tunnel.
\end{abstract}

Keywords: Gladiolus, protected cultivation, rainy season.

\section{Introduction}

Gladiolus (Gladiolus $s p$ ) is an important cut flower grown in many countries in the world. It is frequently used as a cut flower in social and religious ceremonies (Mitra, 1992). It is sold at almost every corner of Dhaka city by the retailers (Hossain, 1995). In Bangladesh, its demand is increasing because of its elegant spike, rich varied colours and long vase life. Now a days, the farmers are commercially cultivating this crop in Bangladesh. Its availability in the market is mostly concentrated during the winter season. Production of gladiolus is largely influenced by planting time, fertilizer management, variety, corm size, etc. (Arora and Khanna, 1990; Khanna and Gill, 1983; Islam et al., 2003). Production and supply of gladiolus flower in summer or rainy summer is very limited due to adverse weather conditions. But, there is a good scope of producing gladiolus flower round the year as was reported by Ara et al. (2003). The farmers are unable to grow gladiolus in the rainy season due to absence of suitable variety and production technologies. Adequate research work to select suitable variety and technology to grow gladiolus round the year is scanty. Therefore, the present investigation was undertaken to find the possibility of growing two gladiolus cultivars under protected and open field condition in the rainy season.

\footnotetext{
${ }^{1}$ Senior Scientific Officer, HRC, Bangladesh Agricultural Research Institute (BARI),
} Gazipur and ${ }^{2}$ Chief Scientific Officer (Rtd.), RARS, BARI, Hathazari (Rtd), Bangladesh. 


\section{Materials and Method}

The experiment was carried out at the Agriculture Research Station, Pahartali, Chittagong during May to November 2002. The experimental design was RCB (Factorial) with three replications. Three factors viz., variety, planting time, and plant protection were considered in this study. Two gladiolus cultivars (GL-023 and GL-027) were planted on two dates under poly tunnel and without poly tunnel. Unit plot size was $1.5 \mathrm{~m}$ and $1.0 \mathrm{~m}$ where plants were spaced $25 \times 15 \mathrm{~cm}$. Corms were sown in 1 May and 1 July in well prepared soil. The soil was prepared thoroughly and cowdung, urea, TSP, and MP were applied @ 5 tons, 150,225 and $130 \mathrm{~kg}$ per hectare respectively (Jana, 1990). The entire quantity of cowdung, TSP, and half of the MP were applied at land preparation, while urea and half of the MP were applied in two equal splits at 40 and 65 days after planting. Poly tunnels were provided as per treatment. Irrigation, drainage, and other intercultural operations were done as and when necessary. Five plants were selected randomly for collection of data. Recorded data were statistically analyzed for interpretation of results.

\section{Results and Discussion}

Analysis of variance revealed that genotype (Factor A), time of planting (Factor B), and plant protection (Factor C) had significant influence on some growth and yield parameters of gladiolus. Interaction effects among genotype, time of planting, and plant protection were also significant for the parameters of plant height, spike length, and rachis length. None of the parameters was significantly affected due to interaction between genotype $\times$ time of planting. On the other hand, the characters, number of cormels per plant, and rachis length were significantly influenced due to interaction between genotype $\times$ plant protection and planting time $\times$ plant protection, respectively. Therefore, discussion for the interactions between genotype $\times$ time of planting, genotype $\times$ plant protection, and time of planting $\times$ plant protection was not made in the present study.

\section{Effect of genotype}

Significant variation was recorded for the characters of plant height, length of spike, and length of rachis (Table 1). Height of the genotype GL-027 was significantly higher $(73.8 \mathrm{~cm})$ as compared to genotype GL-023 $(70.4 \mathrm{~cm})$. Similarly, length of spike $(97.2 \mathrm{~cm})$ and length of rachis $(51.7 \mathrm{~cm})$ of variety GL027 were found higher than those of genotype GL-023 $(92.6 \mathrm{~cm}$ and $48.9 \mathrm{~cm}$, respectively). Misra and Singh (1983) reported similar results on plant height, spike and rachis length, flower colour, corm, and cormel production in gladiolus. Considering the number of florets per spike, corm, and cormel production, both the varieties were equally good for rainy summer production. 
Table 1. Effect of variety, planting time and protection on the growth and flower yield in gladiolus.

\begin{tabular}{|c|c|c|c|c|c|c|c|c|c|c|}
\hline Treatment & $\begin{array}{l}\text { Plant } \\
\text { height } \\
(\mathrm{cm})\end{array}$ & $\begin{array}{c}\text { No. of } \\
\text { leaves/ } \\
\text { plant }\end{array}$ & $\begin{array}{l}\text { Days to } \\
\text { spike } \\
\text { initiation }\end{array}$ & $\begin{array}{l}\text { Length } \\
\text { of spike } \\
(\mathrm{cm})\end{array}$ & $\begin{array}{l}\text { Length } \\
\text { of rachis } \\
\quad(\mathrm{cm})\end{array}$ & $\begin{array}{l}\text { No. of } \\
\text { florets/ } \\
\text { spike }\end{array}$ & $\begin{array}{c}\text { No. of } \\
\text { corms/ } \\
\text { plant }\end{array}$ & $\begin{array}{c}\text { No. of } \\
\text { cormels/ } \\
\text { plant }\end{array}$ & $\begin{array}{l}\text { Wt. of } \\
\text { corms/ } \\
\text { plant }(g)\end{array}$ & $\begin{array}{c}\text { Wt. of } \\
\text { cormels/ } \\
\text { plant } \\
(\mathrm{g})\end{array}$ \\
\hline \multicolumn{11}{|l|}{ Genotype } \\
\hline GL-023 & 70.4 & 10.4 & 83.4 & 92.6 & 48.9 & 12.0 & 1.0 & 8.2 & 15.4 & 30.6 \\
\hline GL-027 & 73.8 & 10.5 & 83.7 & 97.2 & 51.7 & 12.3 & 1.1 & 7.7 & 15.6 & 28.6 \\
\hline F-test & $*$ & ns & ns & & & ns & ns & ns & ns & ns \\
\hline $\operatorname{LSD}(5 \%)$ & 3.01 & - & - & 4.10 & 2.05 & - & - & - & - & - \\
\hline \multicolumn{11}{|l|}{ Time of planting } \\
\hline May 1 & 69.8 & 11 & 79.8 & 92.0 & 46.2 & 12.4 & 1.1 & 7.8 & 15.0 & 28.9 \\
\hline July 1 & 74.4 & 9.9 & 87.0 & 97.0 & 54.4 & 11.9 & 1.0 & 8.0 & 16.0 & 30.3 \\
\hline F-test & $* *$ & ns & & $*$ & $* *$ & ns & ns & ns & & $*$ \\
\hline LSD (5\%) & - & - & - & 4.55 & - & - & - & - & 0.87 & 1.56 \\
\hline LSD (1\%) & 3.10 & - & 5.23 & - & 6.85 & - & - & - & - & - \\
\hline \multicolumn{11}{|l|}{ Protection } \\
\hline Withpolyturinel & 71 & 10.4 & 82.5 & 95.3 & 49.9 & 12.8 & 1.2 & 7.6 & 16 & 30.6 \\
\hline Withoutpolytunnel & 73 & 10.4 & 84.6 & 94.5 & 50.7 & 11.5 & 1.0 & 8.2 & 15 & 28.7 \\
\hline F-test & & ns & $* *$ & $\mathrm{~ns}$ & ns & & ns & & $* *$ & $*$ \\
\hline $\operatorname{LSD}(5 \%)$ & 1.85 & - & - & - & - & 1.03 & - & 0.31 & - & 1.55 \\
\hline LSD (1\%) & - & - & 2.01 & - & - & & - & - & 0.86 & - \\
\hline $\mathrm{CV}(\%)$ & 4.2 & 6.7 & 1.8 & 5.7 & 8.6 & 7.3 & 7.4 & 3.6 & 3.8 & 4.8 \\
\hline
\end{tabular}

* Significant at $5 \%$ level of probability

** Significant at $1 \%$ level of probability

$\mathrm{ns}=$ not significant 
Table 2. Interaction effect among factors on the growth and yield in gladiolus.

\begin{tabular}{|c|c|c|c|c|c|c|c|c|c|c|}
\hline Treatment & $\begin{array}{c}\text { Plant } \\
\text { height } \\
(\mathrm{cm})\end{array}$ & $\begin{array}{c}\text { No. of } \\
\text { leaves/ } \\
\text { plant }\end{array}$ & $\begin{array}{l}\text { Days to } \\
\text { spike } \\
\text { initiation }\end{array}$ & $\begin{array}{l}\text { Length of } \\
\text { spike } \\
(\mathrm{cm})\end{array}$ & $\begin{array}{l}\text { Length of } \\
\text { rachis } \\
(\mathrm{cm})\end{array}$ & $\begin{array}{c}\text { No. of } \\
\text { florets/ } \\
\text { spike }\end{array}$ & $\begin{array}{c}\text { No. of } \\
\text { corms/ } \\
\text { plant }\end{array}$ & $\begin{array}{c}\text { No. of } \\
\text { cormels/ } \\
\text { plant }\end{array}$ & $\begin{array}{c}\text { Wt of } \\
\text { corms/ } \\
\text { plant }(\mathrm{g})\end{array}$ & $\begin{array}{c}\text { Wt of } \\
\text { cormels/ } \\
\text { plant }(\mathrm{g})\end{array}$ \\
\hline VITIP1 & $67.0 \mathrm{C}$ & 11.0 & 78.3 & $93.1 \mathrm{~b}$ & $48.5 b$ & 13.2 & 1.2 & 7.7 & 15.5 & 30.5 \\
\hline VITIP2 & $68.0 \mathrm{C}$ & 10.6 & 82.0 & $84.0 \mathrm{c}$ & $42.6 \mathrm{e}$ & 11.1 & 1.0 & 8.4 & 14.0 & 30.2 \\
\hline VIT2P1 & $71.0 \mathrm{bc}$ & 10.2 & 86.0 & $94.3 \mathrm{ab}$ & $46.8 \mathrm{de}$ & 12.6 & 1.2 & 7.9 & 16.3 & 32.2 \\
\hline VIT2P2 & $75.6 \mathrm{a}$ & 9.7 & 87.6 & $99.0 \mathrm{ab}$ & $57.3 \mathrm{ab}$ & 11.2 & 1.0 & 8.7 & 15.8 & 29.5 \\
\hline V2TIP1 & $69.3 \mathrm{a}$ & 10.9 & 79.0 & $96.7 \mathrm{ab}$ & $50.2 \mathrm{~cd}$ & 12.7 & 1.3 & 7.5 & 16.4 & 28.6 \\
\hline V2TIP2 & $75.0 \mathrm{ab}$ & 11.4 & 80.0 & $94.0 \mathrm{ab}$ & $43.4 \mathrm{e}$ & 12.8 & 1.0 & 7.0 & 14.3 & 26.5 \\
\hline V2T2P1 & $77.0 \mathrm{a}$ & 9.7 & 87.0 & $97.1 \mathrm{ab}$ & $54.1 \mathrm{bc}$ & 13.0 & 1.1 & 7.8 & 16.0 & 31.0 \\
\hline $\mathrm{V} 2 \mathrm{~T} 2 \mathrm{P} 2$ & $74.0 \mathrm{ab}$ & 10.1 & 89.0 & $101.0 \mathrm{a}$ & $59.3 \mathrm{a}$ & 11.0 & 1.0 & 7.7 & 15.8 & 28.5 \\
\hline F- test & & ns & ns & & & ns & ns & ns & ns & ns \\
\hline $\operatorname{LSD}(5 \%)$ & 4.5 & - & - & 7.8 & 4.7 & - & - & - & - & - \\
\hline $\mathrm{CV}(\%)$ & 4.2 & 6.7 & 1.8 & 5.7 & 8.6 & 7.1 & 7.4 & 3.6 & 3.8 & 4.8 \\
\hline
\end{tabular}

Means followed by same letter (s) in a column are not significantly different by LSD

*Significant at $5 \%$ level of probability

$\mathrm{ns}=$ Not significant

$\mathrm{V} 1=\mathrm{GL}-023, \mathrm{~T} 1=$ May $1, \mathrm{P} 1=$ with poly tunnel

$\mathrm{V} 2=$ GL-027, T2 = July 1, P2 = without poly tunnel 


\section{Effect of planting time}

Effect of planting time on gladiolus production is shown in Table 1. Time of planting had significant influence on plant height, number of leaves per plant, days to spike initiation, spike and rachis length. Other important characters like corm and cormel production were also significantly influenced by the planting time. Planting in July produced taller plant $(74.4 \mathrm{~cm})$ than the planting of May $(69.8 \mathrm{~cm})$. However, plants of both dates of planting were much taller in summer than winter season crop. It was reported that the plant height of winter season crop lies between 45 and $55 \mathrm{~cm}$ (Islam et al., 2000; Ara et al., 2003). High temperature and high humidity were probably responsible for the increased plant height and number of leaves per plant (Asahira et al., 1968; Imanishi et al., 1970). Days to spike initiation was earlier for May planting (79.8 days) than that of July planting (87.0 days). However, Ara et al. (2003) reported 90 and 81 days were required for spike initiation for May and June planting, respectively. Spike and rachis length were significantly higher in July planting compared to May planting. In respect of corm $(\mathrm{g})$ and cormel $(\mathrm{g})$ production, July planting was better than May planting. Congenial weather condition during the later part of July planting might be responsible for the production of longer spike and rachis, higher amount of corm and cormel production.

\section{Effect of plant protection}

Effect of plant protection on gladiolus production is shown in Table 1. Some of the characters were largely affected due to plant protection. Plants grown under poly tunnel produced flower earlier (82.5 days) compared to plants grown without poly tunnel (84.6 days). Again plants grown under poly tunnel performed better in respect of florets per spike, number of cormels per plant, weight of corm and weight of cormels than those grown without poly tunnel. Poly tunnels protected the plants from heavy shower.

\section{Interaction effect among the factors (Genotype $\times$ Planting time $\times$ Plant protection)}

Interaction effects of different factors on plant growth and yield of gladiolus is presented in Table 2. The plant height, length of spikes and length of rachis were significantly influenced by interaction among the factors. The genotype GL-027 produced the tallest plant $(77.0 \mathrm{~cm})$ at July planting when grown under poly tunnels. It was closely followed by the genotype GL-023 $(75.6 \mathrm{~cm})$ at July planting when grown without poly tunnels. The highest lengths of spike (101.0 $\mathrm{cm})$ and rachis $(59.3 \mathrm{~cm}$ ) were recorded from the genotype GL-027 when planted in July without poly tunnels. The other characters were not significantly affected due to the interaction of the three factors. 
The present results suggest that poly tunnel is useful to produce gladiolus during the summer season in Bangladesh.

\section{References}

Ara, R., F. N. Khan, S. A. Chowdhury and M. A. Goffar. 2003. Effects of planting time on year round flower and corm production of gladiolus. Bangladesh J. Agril. Res. 28(1): 9-14.

Arora, J. S. and K. Khanna. 1990. Studies on corm production in gladiolus as affected by corm sizes. Indian J. Hort. 47(4): 442-446.

Asahira, T., H. Imanishi and Y. Tsukamoto. 1968. Studies on the cormel formation in gladiolus. Mem. Coll. Agric. Kyoto Univ. 93:21-34.

Hossain, M. M. 1995. Plant tissue culture. Bangabandhu Sheikh Mujibur Rabman Agricultural University, Gazipur. p. 35.

Jana, B. 1990. Fuler Bagan (in Bengali). Bidhan Chandra Krishi Vishyvidhyalay, West Bengal, India. p. 80.

Khanna, K. and A. P. S. Gill. 1983. Effect of planting time of gladiolus corms on flower and cormel production. Punjab Hort. Journal 23(1/3): 116-120.

Imanishi, H., K. Sasaki and M. Oen. 1970. Further studies on the cormel formation in gladiolus. Bull Univ. Oska Pref. Ser. B. 22: 7-17.

Islam, M. S., S. S. Chowdhury, A. S. M. G. Hafiz and M. A. Malek. 2000. The effect of corm size on the production of flower, corm, and cormel in gladiolus. Bangladesh J. Agril. Res. 25(1): 33-37

Misra, R. L., and B. Singh. 1983. Gladiolus. In: Bose, T. K. and L. P. Yadav. Commercial Flower. 1st Ed. Naya Prokash, Calcutta, India, p. 267.

Mitra, R. 1992. Gladiolus. Fuler Bagan (31 part). Indian Book Agency, 11/27, Temer Lane, Calcutta, pp.158-168. 